\title{
UNDANG UNDANG NOMOR 28 TAHUN 2014 TENTANG HAK CIPTA DAN PERLINDUNGAN HUKUM BAGI PENCIPTA KARYA CIPTA MUSIK DAN LAGU
}

\author{
Oleh: Hulman Panjaitan \\ Hulman234@yahoo.com Universitas \\ Kristen Indonesia, Jakarta, Indonesia
}

\section{Abstract}

The meaning of song and music is different, but copyright literature does not seem to distinguish them. In the library of international law, the term commonly used to refer to a song or music is musical work. The Bern Convention states that one of the protected works is music compositions with or without words. There is no explicit description in the Bern Convention about what musical work really is. However, from the existing provisions it can be concluded that there are two types of music creation that are protected by copyright, namely music with words and music without words. Music with meaningful words is a song whose elements consist of melody, arrangement lyrics, and notation, while music without words is music that only consists of elements of melody, arrangement and notation.

Keywords: copyright literature; the Bern Convention; protected works.

\section{PENDAHULUAN}

Bagi setiap pencipta, keahlian mencipta bukan saja merupakan kelebihan dan atau anugerah dari Tuhan Yang Maha Kuasa. Baginya, keahlian itu juga menjadi sumber penghidupannya. Dari keahlian yang dimiliki, pencipta memperoleh nafkah. Sama halnya dengan manusia lain yang memiliki keahlian di bidang tertentu dan menjadikannya sebagai sumber penghidupan. Keahlian mencipta adalah profesi. Manusia disekitarnya bukan saja ikut menikmati, tetapi juga untuk memenuhi sebagian kebutuhan hidupnya atau bahkan kepentingan ekonominya.

Dasar pembenaran dari perlunya perlindungan hukum bagi pencipta yang paling klasik didasarkan kepada teori hukum alam yang menekankan kepada faktor manusia dan penggunaan akal. Thomas Aquinas salah satu pelopor hukum alam dari negaranegara yang menganut sistem civil law mengatakan bahwa "hukum alam merupakan hukum akal budi. Oleh karena itu, hanya diperuntukkan bagi makhluk yang rasional. Hukum alam lebih merupakan hukum yang rasional. Menurut teori hukum alam, "pencipta memiliki hak moral untuk menikmati hasil kerjanya, termasuk keuntungan yang dihasilkan oleh keintelektualannya”. Di samping itu, karena pencipta telah memperkaya masyarakat melalui ciptaannya, pencipta memiliki hak untuk mendapatkan imbalan yang sepadan dengan nilai sumbangannya. Jadi hak cipta, memberi hak milik eksklusif atas suatu karya pencipta. Hal ini berarti "mempertahankan hukum alam dari individu untuk mengawasi karya-karyanya dan mendapat konpensasi yang adil atas sumbangannya kepada masyarakat".

Berdasarkan pemikiran teori hukum alam tersebut, diperlukan adanya perlindungan hukum kepada para pencipta atas ciptaannya. Perlindungan hukum adalah adanya jaminan hak dan kewajiban untuk manusia dalam rangka memenuhi kepentingan sendiri maupun didalam hubungan dengan manusia lainnya. Kepentingan manusia yang dilindungi oleh hukum biasa disebut hak dan memberikan wewenang kepada seseorang untuk melakukan perbuatan dapat dipersamakan kepada siapun dan sebaliknya setiap orang harus menghormati hak itu". Perlindungan hukum merupakan upaya yang diatur dalam undang-undang untuk mencegah terjadinya pelanggaran hukum. Dapat juga dikemukakan bahwa perlindungan hukum adalah berkaitan dengan tindakan negara untuk melakukan sesuatu dengan (memberlakukan hukum negara secara eksklusif) dengan tujuan untuk memberikan jaminan kepastian hak-hak seseorang atau kelompok orang. 
Perlindungan hukum kepada pencipta (lagu atau musi) diberikan melalui pranata peraturan perundangan-undangan yang berkaitan dengan hak cipta, baik pengaturan secara internasional maupun melalui peraturan perundang-undangan nasional. Dalam sejarah peraturan perundang-undangan di Indonesia, terdapat sejumlah perundang-undangan hak cipta yang pernah diberlakukan, mulai dari auteurswet 1912, Stb No. 600 tahun 1912 tentang hak pengarang, yang berlaku sejak 23 September 1912, kemudian berturut-turut adalah Undang Undang Nomor 6 Tahun 1982 tentang Hak Cipta, Lembaran Negara Republik Indonesia Tahun 1982 Nomor 15, Tambahan Lembaran Negara republik Indonesia No. 3217, Undang Undang Nomor 7 Tahun 1987 tentang Perubahan Atas Undang Undang Nomor 6 Tahun 1982 tentang Hak Cipta, Lembaran Negara Republik Indonesia Tahun 1987 Nomor 42, Tambahan Lembaran Negara Republik Indonesia No. 3362, Undang Undang Nomor 12 Tahun 1997 tentang Perubahan Kedua Atas Undang Undang Nomor 6 Tahun 1982 tentang Hak Cipta, Lembaran Negara Republik Indonesia Tahun 1997 Nomor 29, Tambahan Lembaran Negara republik Indonesia No. 3679, Undang Undang Nomor 19 Tahun 2002 tentang Hak Cipta, Lembaran Negara Republik Indonesia Tahun 2002 Nomor 85, Tambahan Lembaran Negara Republik Indonesia No. 4220 dan terakhir dengan Undang Undang Nomor 28 Tahun 2014 tentang Hak Cipta, Lembaran Negara Republik Indonesia Tahun 2014 Nomor 266, Tambahan Lembaran Negara Republik Indonesia No. 5599.

Dari sekian banyak ciptaan yang dilindungi menurut undang-undang ${ }^{1}$, pada kesempatan ini, penulis akan lebih mengkhususkan pembahasan pada hak 1 Menurut Pasal 40 UU No. 28 Tahun 2014 tentang Hak Cipta, ciptaan yang dilindungi adalah : a). buku, pamplet, perwajahan karya tulis yang diterbitkan dan semua hasil karya tulis lainnya; b). ceramah, kuliah, pidato dan ciptaan sejenis lainnya; c). alat peraga yang dibuat untuk kepentingan pendidikan dan ilmu pengetahuan; d). lagu dan/atau music dengan atau tanpa teks; e). drama, drama musical, tari, koreografi, pewayangan dan pantomin;f). karya seni rupa dalam segala ebntuk seperti lukisan, gambar, ukiran, kaligrafi, seni pahat, patung atau kolase;g). karya seni terapan;h). karya arsitektur;i). peta;j). karya

seni batik atau seni motif lain; k). karya fotografi; I). potert; $\mathrm{m})$. karya sinematografi; $n$ ). terjemahan, tafsir, saduran, bunga rampai, basis data, adaptasi, aransemen, modifikasi dan karya lain dari hasil transformasi; 0). Terjemahan, adaptasi, aransemen, transformasi atau modifikasi ekspresi budaya tradisional; p). kompilasi ciptaan atau data, baik dalam format yang dapat dibaca dengan program computer maupun media lainnya; q). kompilasi ekspresi budaya tradisional selama kompilasi tersebut merupakan karya yang asli; r). permaninan video, dan; s). program komputer. cipta musik dan lagu, mengingat maraknya pelanggaran yang terjadi atas hak cipta ini, baik pelanggaran dalam hal mechanical right (hak untuk mengumumkan) maupun dalam hal performing right (hak untuk memperbanyak).

\section{PEMBAHASAN \\ Hak Cipta Sebagai Hak Eksklusif}

Undang Undang melalui Pasal 1 angka (1) UUHC telah menetapkan bahwa Hak Cipta adalah hak eksklusif pencipta yang timbul secara otomatis berdasarkan prinsip deklaratif setelah suatu ciptaan diwujudkan dalam bentuk yata tanpa mengurangi pembatasan sesuai dengan ketentuan peraturan perundang-undangan. Artinya adalah hak yang semata-mata hanya diperuntukkan bagi pencipta dan atau pemegang hak ciptanya dan karenanya tidak ada pihak lain yang dapat mengambil manfaat ekonomi tanpa izin terlebih dahulu dari pencipta dan atau dari pemegang hak ciptanya. Dengan sifatnya yang eksklusif, pemilik hak cipta berhak untuk mengizinkan pihak lain menggunakan karya ciptanya, sebaliknya juga dapat melarang pihak lain untuk menggunakan karya ciptanya tersebut. Hak-hak eksklusif itu adalah esensi dari kepemilikan hak cipta.

Melalui Pasal 9 ayat (2) UUHC dinyatakan bahwa setiap orang yang melaksanakan hak ekonomi sebagaimana dimaksud pada ayat $(1)^{2}$ wajib mendapatkan izin pencipta atau pemegang hak cipta. Selanjutnya dalam ayat (3) dijelaskan bahwa setiap orang yang tanpa izin pencipta atau pemegang hak cipta dilarang melakukan penggandaan dan/atau penggunaan secara komersial ciptaan. Permasalahan selanjutnya adalah siapakah yang dimaksud dengan "setiap orang" atau "pihak lain" dalam Pasal 9 UUHC yang oleh undangundang dilarang mengambil manfaat dari karya cipta musik dan lagu tersebut tanpa seizin dari pencipta dan atau pemegang hak ciptanya. Pihak lain yang dimaksud adalah mereka yang menggunakan karya

\footnotetext{
2 Pasal 9 ayat (1) UUHC menetapkan bahwa pencipta atau pemegang hak cipta sebagaimana dimaksud dalam Pasal 8 memiliki hak ekonomi untuk melakukan : a). penerbitan ciptaan; b). penggandaan ciptaan; c). penerjemahan ciptaan; d) pengadaptasian, pengaransemenan atau pentransformasian ciptaan; e). pencistribusian ciptaan atau salinannya; f). pertunjukan ciptaan;g). pengumuman ciptaan; h). komunikasi ciptaan, dan;i). penyewaan ciptaan.
} 
cipta musik untuk suatu kegiatan komersial dan atau kepentingan yang berkaitan dengan kegiatan komersial. UUHC menentukan kriteria "Penggunaan Secara Komersial", yaitu pemanfaatan ciptaan dengan tujuan untuk memperoleh keuntungan ekonomi dari berbagai sumber atau berbayar. Diantaranya adalah hotel, rumah sakit, mal, pertokoan, retail business, salon, spa \& fitness, restoran, pub dan café, karaoke dan discotheque, transportasi, terminal, digital transmission, cinema, broadcaster, one off event, tiket selling background music, dan sebagainya. Usaha-usaha seperti dikemukakan diatas, sudah barang tentu baik secara langsung maupun secara tidak langsung telah mendapatkan manfaat ekonomis dari penggunaan karya cipta musik dan lagu dan karenanya mereka wajib meminta izin terlebih dahulu kepada penciptanya serta melakukan pembayaran royalti sebagai kewajiban hukumnya.

Pemberian izin dalam penggunaan karya cipta musik dan lagu oleh para pengguna (user) sebagaimana diuraikan diatas dilakukan dengan perjanjian lisensi. Lisensi itu sendiri adalah izin yang diberikan oleh pemegang hak cipta (musik) kepada pihak lain untuk melaksanakan hak ekonomi atas ciptaannya dengan syarat tertentu. Lisensi pengumuman musik diberikan berdasarkan surat perjanjian lisensidisertai kewajiban pembayaran royalti kepada pemegang hak cipta. Royalti adalah bentuk pembayaran yang dilakukan kepada pemegang hak cipta (musik) karena tidak dapat memanfaatkan sendiri kepemilikannya.Jumlah royalti yang wajib dibayar kepada pemegang hak cipta musik oleh penerima lisensi sesuai undang-undang ditetapkan berdasarkan kelaziman dalam praktik yang berlaku dengan memenuhi unsur keadilan.

\section{Karya Cipta Musik dan Lagu}

Di dalam UUHC tidak terdapat pengaturan khusus tentang pengertian ciptaan lagu dan/atau musik. Ia hanya merupakan salah satu karya yang dilindungi melalui UUHC sebagaimana juga karya-karya lain yang dicantumkan dalam Pasal 40. Tepatnya diatur dalam Pasal 40 ayat (1) sub (d), yaitu ciptaan lagu atau musik dengan atau tanpa teks. Oleh karena itu, terhadap lagu dan/atau musik berlaku semua aturan umum yang juga berlaku untuk karya lainnya, kecuali disebutkan secara khusus tidak berlaku.
Dalam penjelasan Pasal 40 ayat (1) UUHC ini khususnya sub (d) ditegaskan bahwa karya lagu atau musik dalam pengertian undang-undang diartikan sebagai satu kesatuan karya cipta yang bersifat utuh. Pengertian utuh dimaksudkan bahwa lagu atau musik tersebut merupakan suatu kesatuan karya cipta.

Secara etimologi, lagu atau musik pada dasarnya mempunyai perbedaan arti. Lagu adalah suatu kesatuan musik yang terdiri atas susunan pelbagai nada yang berurutan. Setiap lagu ditentukan oleh panjangpendek dan tinggi rendahnya nada-nada tersebut, disamping itu irama juga memberi corak tertentu kepada suatu lagu.

Menurut Kamus Besar Bahasa Indnesia), yang dimaksud dengan lagu adalah : 1). Ragam suara yang berirama (dalam bercakap, bernyayi, membaca, dan sebagainya); 2). Nyanyian; 3). Ragam nyanyi (musik, gamelan dan sebagainya)-keroncong asli; 4). Tingkah laku; cara; lagak. Sedangkan musik adalah : 1). Ilmu atau seni menyusun nada atau suara dalam urutan kombinasi dan hubungan temporal untuk menghasilkan komposisi (suara) yang mempunyai kesatuan dan kesinambungan; 2). Nada atau suara yang disusun demikian rupa sehingga mengandung irama, lagu dan keharmonisan (terutama yang menggunakan alat-alat yang dapat menghasilkan bunyi-bunyian itu).

Pada dasarnya semua musik berisi elemen-elemen dasar tertentu, yaitu rhythm, melody, harmony dan form. Rhythm meliputi jangka waktu atau panjang suara musik. Isi dari rhythm adalah getaran atau gerakan irama yang tetap (steady beat), ukuran (meter), dan tekanan (accent). Jika gerakan irama (beat) digabung dalam satu kumpulan dua, tiga atau lebih dalam satu ukuran, hasilnya disebut meter. Ukuran dari ketukan kuat atau lemahnya tekanan diulang terus menerus sebagai irama satu, dua, tiga,... satu, dua, tiga.

Melody, terdiri dari pola titi nada (pitch) atau tinggi rendahnya nada (tone). Beberapa macam musik atau tipe musik hampir kesemuanya terdiri dari melody. Tipe yang lain mungkin juga berdasarkan pada suatu tema (motif) atau pengulangan rangkaian nada-nada (notes). Jika melody dalam komposisi yang panjang diulang pada bentuk yang berbeda, nada dasar ini disebut tema atau pokok. Harmony, tertuju pada bentuk bunyi paduan nada (chord) yang dimainkan bersama 
dan diperoleh dari ukuran dasar musik. Hal itu juga meliputi perintah rangkaian bentuk bunyi paduan nada yang menyertai melodi. Awal melodi adalah lagu (tone) nada dasar yang sama (monotone) atau hampir dengan tiada suatu selingan (variation), tetapi perubahan harmoni ditambah warna, getaran dan pelepasan gubahan (composition).

Sedangkan form, merupakan hasil dari rhythm, melody dan harmony yang disetel atau dipasang (to put together). Musik yang bagus memiliki kesatuan untuk memuaskan telinga pendengar dan selingan untuk memelihara minat. Bahkan sebuah aransemen dari suatu musik jika dengan mengikuti irama sebuah musik tertentu dapat dipakai sebagai terapi penyembuhan penderita narkoba.

Sekalipun pengertian lagu dan musik berbeda, tetapi kepustakaan hak cipta tampaknya tidak membedakannya. Di dalam kepustakaan hukum internasional, istilah yang lazim digunakan untuk menyebutkan lagu atau musik adalah musical work. Konvensi Bern menyebutkan salah satu work yang dilindungi adalah komposisi musik (music compositions) dengan atau tanpa kata-kata (with or without words). Tidak ada uraian yang tegas dalam Konvensi Bern tentang apa sesungguhnya musical work itu. Namun, dari ketentuan yang ada dapat disimpulkan bahwa ada dua jenis ciptaan musik yang dilindungi hak cipta, yaitu musik dengan kata-kata dan musik tanpa kata-kata. Musik dengan kata-kata berarti adalah lagu yang unsurnya terdiri dari melodi, lirik arransemen, dan notasi, sedangkan musik tanpa kata-kata adalah musik yang hanya terdiri dari unsur melodi, arransemen dan notasi.

Dalam kaitannya dengan perlindungan suatu karya cipta lagu dan/atau musik, yang sering dipersoalkan adalah, lagu atau musik yang bagaimanakah yang dilindungi sebagai suatu ciptaan menurut undangundang. Permasalahan ini menjadi penting karena bisa saja banyak orang menyanyikan lagu yang melodi dan liriknya sembarangan atau dapat memainkan alat musik yang menghasilkan nada-nada yang tidak jelas. Sebagaimana diuraikan sebelumnya bahwahak cipta hanya melindungi ide yang sudah berwujud atau memiliki bentuk (psycal form) dan asli (original). Perlindungan hak cipta tidak pernah diberikan pada ide atau gagasan karena karya cipta harus memiliki bentuk yang khas, bersifat pribadi dan menunjukkan keaslian sebagai ciptaan yang lahir berdasarkan kemampuan, kreativitas dan keahlian sehingga ciptaan itu dapat dibaca dan didengar. Sehingga dengan demikian, lagu yang dinyanyikan dengan melodi dan lirik yang sembarangan bukanlah suatu ciptaan yang dilindungi menurut undang-undang.

\section{UU Nomor 28 Tahun 2014 tentang Hak Cipta dan Perlindungan Hukum Kepada Pencipta Lagu atau Musik}

Berikut ini secara deskriptif akan diuraikan seperti apa ketentuan dalam UUHC yang memberikan perlindungan perlindungan kepada pencipta musik dan lagu. Bilamana dalam UU No. 19 tahun 2002 tentang hak cipta memberikan jangka waktu perlindungan terhadap karyua cipta lagu atau musik adalah seumur hidup si pencipta ditambah dengan 50 (lima puluh) tahun setelah pencipta meninggal dunia (vide Pasal 29), maka menurut UU No. 28 tahun 2014 diberikan seumur hidup si pencipta ditambah dengan 70 (tujuh puluh) tahun setelah pencipta meninggal dunia (vide Pasal 58). Ketentuan yang baru yang tidak ditemukan dan tidak diatur dalam UUHC sebelumnya yang diatur dalam UU No. 28 Tahun 2014 adalah berkaitan dengan keberadaan collective society yang oleh UU No. 28 Tahun 2014 dikenal sebagai Lembaga Manajemen Kolektif yang disingkat LMK, yaitu institusi yang berbentuk badan hukum nirlaba yang diberi kuasa oleh Pencipta, Pemegang Hak Cipta guna mengelola hak ekonominya dalam bentuk menghimpun dan mendistribusikan royalti. Saat ini jumlah LMK yang mendapat Surat Keputusan dari Menteri Hukum dan HAM RI diantaranya adalah Karya Cipta Indonesia (KCI), Wahana Musik Indonesia (WAMI), Royalti Anugerah Indonesia (RAI) untuk melaksanakan pengadministrasian kolektif atas pemakaian hak cipta dari para pencipta lagu dan/atau musik, baik ciptaan Indonesia maupun asing.

UUHC menetapkan bahwa untuk mendapatkan hak ekonomi setiap Pencipta, Pemegang Hak Cipta menjadi anggota Lembaga Manajemen Kolektif agar dapat menarik imbalan yang wajar dari pengguna yang memanfaatkan Hak Cipta dalam bentuk layanan publik yang bersifat komersial. Pengguna sebagaimana 
dimaksud pada ayat (1) membuat perjanjian dengan Lembaga Manajemen Kolektif yang berisikewajiban untuk membayar royalti atas Hak Cipta yang digunakan. Permasalahan muncul adalah, apakah seorang pencipta atau pemegang hak cipta lagu atau musik yang belum menjadi anggota dari suatu LMK dapat menuntut pihak lain (user) yang mempergunakan karya ciptanya tanpa izin ?. Tampaknya tidak bisa, karena dia harus menjadi anggota dulu dalam suatu LMK yang ada.Hal ini bertentangan dengan prinsip asas hukum, yang menyatakan bahwa seseorang yang merasa haknya dilanggar dapat menuntut pihak lain secara perorangan sebagai akibat perbuatan yang merugikan yang dilakukannya. Dengan demikian tidak perlu harus memberi kuasa kepada pihak lain, yang dalam hal ini adalah kepada LMK.

Bagaimana dengan penentuan besarnya royalti ? Sesuai UUHC, besarnya royalti sebagai kewajiban para Pengguna (user) ditetapkan berdasarkan kelaziman praktik yang berlaku dan memenuhi unsur keadilan. Penjelasannya mengemukakan, penghitungan dan pengenaan besarsan royalti perlumemperhatikan elemen yang merupakan dasar penghitungan besarnya royalti, misalnya jumlah kursi, jumlah kamar, luas ruangan, jumlah eksemplar yang disalin sesuai dengan kebiasaan/praktik yang lazim dilakukan.

Kalau dahulu sebelum dikeluarkannya UU No. 28 tahun 2014, kewenangan para collective society tersebut diatas sebagai pemegang hak cipta lagu dan/ atau musik untuk menghimpun dan mendistribusikan royalti kepada pencipta didasarkan kepada surat kuasa dan/atau perjanjian kerjasama dari dan antara para pencipta di dalam negeri dan perjanjian kerjasama (resiprocal agreement) dengan lembaga sejenis di luar negeri sebagai pemegang hak cipta lagu dan/atau musik asing, diantaranya adalah reciprocal agreement antara KCI dengan Music Author's Copyright Protection (MACP) Berhard di Malasya, De Vereniging BUMA di Belanda, American Society of Composers, Authors and Publishers (ASCAP) dan Broadcast Music, Inc (BMI) di Amerika dan lain-lain, maka dengan UU No. 28 Tahun 2014, kewenangan yang dimiliki Lembaga Manajemen Kolektif untuk mengelola hak ekonomi Pencipta dan/atau Pemnegang Hak Cipta untuk menarik, menghimpun dan mendistribusikan royalti adalah didasarkan kepada undang-undang. Dengan pengertian lain, undang-undang memberikan kewenangan kepada LMK untuk mengelola hak ekonomi Pencipta dan/atau Pemegang hak Cipta setelah mendapat izin operasional dari Menteri Hukum dan HAM RI.

Dari segi pidana, terdapat ketentuan baru yang diatur dalam UU No. 28 tahun 2014. Diantaranya adalah hukuman atau pidana yang dapat dijatuhkan kepada pengelola tempat perdagangan yang dengan sengaja dan mengetahui membiarkan penjualan dan/ atau penggandaan barang hasil pelanggaran hak cipta ditempat perdagangan yang dikelolanya sekalipun dengan pidana denda maksimal Rp. 100.000.000,(seratus juta rupiah).

Secara khusus, pengaturan tindak pidana pelanggaran hak cipta musik atau lagu terdapat dalam Pasal 113 UU No. 28 tahun 2014 yang menentukan :

- Setiap orang yang dengan tanpa hak melakukan pelanggaran hak ekonomi sebagaimana dimaksud dalam Pasal 9 ayat (1) huruf (i) untuk penggunaan secara komersial dipidana dengan pidana penjara paling lama 1 (satu) tahun dan/atau denda paling banyak Rp. 100.000.000,- (seratus juta rupiah).

- Setiap orang yang dengan tanpa hak dan/atau tanpa izin pencipta atau pemegang hak cipta melakukan pelanggaran hak ekonomi sebagaimana dimaksud dalam Pasal 9 ayat (1) huruf c, huruf d, huruf $f$ dan/ atau huruf $\mathrm{h}$ untuk penggunaan secara komersial dipidana dengan pidana penjara paling lama 3 (tiga) tahun dan/atau denda paling banyak $\mathrm{Rp}$. 500.000.000,- (lima ratus juta rupiah).

- Setiap orang yang dengan tanpa hak dan/atau tanpa izin pencipta atau pemegang hak cipta melakukan pelanggaran hak ekonomi sebagaimana dimaksud dalam Pasal 9 ayat (1) huruf a, huruf b, huruf e dan/atau huruf $g$ untuk penggunaan secara komersil dipidana dengan pidana penjara paling lama 4 (empat) tahun dan/atau denda paling banyak Rp. 1.000.000.000,- (satu milyar rupiah).

- Setiap orang yang memenuhi unsur sebagaimana dimaksud pada ayat (3) yang dilakukan dalam bentuk pembajakan, dipidana dengan pidana penjara paling lama 10 (sepuluh) tahun dan/atau denda paling banyak Rp. 4.000.000.000,- (empat 
milyar rupiah).

Beberapa hal yang dapat digarisbwahi dengan memperhatikan pengatuarn tindak pidana yang ada dalam Pasl 113 tersebut diatas yang menurut penulis justru merupakan suatu langkah mundur dalam memberikan perlindungan hukum kepada pencipta lagu atau musik, yaitu khusus mengenai ketentuan yang tidak lagi memuat adanya ancaman hukuman minimal sehingga berbeda dengan ketentuan pidana atas pelangaran hak cipta yang sebelumnya diatur dalam Bab XII Pasal 72 Undang Undang Nomor 19 Tahun 2002 tentang Hak Cipta yang menetapkan ancaman hukuman minimal 1 (satu) tahun dan/atau denda paling sedikit Rp. 1.000.000,- (satu juta rupiah). Demikian juga dengan ancaman hukuman maksimal yang dapat dijatuhkan kepada pelanggar hak cipta dalam Undang Undang Nomor 19 Tahun 2002 adalah lebih tinggi yaitu berkisar antara 5 sampai dengan 7 tahun penjara sedangkan dalam Undang Undang Nomor 28 Tahun 2014 berkisar antara 1 (satu) sampai dengan 4 (empat) tahun penjara, kecuali untuk tindak pidana pembajakan dengan ancaman hukuman maksimal 10 (sepuluh) tahun penjara.

Selain itu, melalui Pasal 120 UUHC menentukan bahwa tindak pidana sebagaimana dimaksud dalam undang undang ini merupakan delik aduan. Dengan pengertian bahwa tindak pidana pelanggaran hak cipta baru boleh dilakukan tindakan penyelidikan dan/atau penyidikan setelah adanya pengaduan dari pencipta dan/atau pemegang hak cipta sebagai pihak atau korban yang dirugikan.

Dengan memperhatikan jenis tindak pidana pelanggaran hak cipta sebagai suatu delik aduan (klacht delict) sebagaimana diatur dalam Pasal 120 UUHC, dapat dikemukakan bahwa sesungguhnya keberadaan dan kehadiran UU ini justru merupakan langkah mundur dalam memberikan perlindungan hukum bagi pencipta di Indonesia, karena undang undang Hak Cipta yang baru ini telah menjadikan pelanggaran hak cipta sebagai suatu delik aduan, yang sebelumnya menurut peraturan perundang undangan hak cipta yang tersebut dalam Undang Undang Nomor 7 Tahun 1987, yang kemudian dirubah dengan Undang Undang Nomor 12 Tahun 1997 dan Undang Undang Nomor 19 Tahun 2002 Tentang Hak Cipta merupakan tindak pidana kejahatan biasa. Hal ini justru merupakan suatu kemunduran dalam kaitannya dengan pemberian perlindungan hukum bagi pencipta lagu atau musik. Konsekwensi hukumnya adalah aparat penegak hukum tidak perduli terhadap penegakan hukum atas pelanggaran hak cipta walaupun hal itu terjadi di depan matanya bila tidak ada pengaduan dari pihak yang haknya dilanggar.

Memang dalam undang-undang hak cipta sebelumnya yang tersebut dalam Undang Undang Nomor 6 Tahun 1982 mengatur tindak pidana atas pelanggaran hak cipta adalah merupakan delik aduan. Namun penentuan jenis pidana sebagai delik aduan dalam UU No. 6 Tahun 1982 ini justru dianggap sebagai salah satu kelemahan dari Undang Undang Nomor 6 Tahun 1982 dalam menanggulangi pelanggaran hak cipta karena peraturan pidananya sebagai delik aduan. Penyidik baru dapat melakukan penangkapan terhadap pelakunya setelah adanya pengaduan dari pihak korban". Dan bila dilihat dari sejarah peraturan perundang-undangan hak cipta, justru dapat diketahui bahwa salah satu alasan perubahan UU No. 6 Tahun 1982 tentang Hak Cipta dengan UU No. 7 Tahun 1987 tentang Perubahan Atas UU No. 6 Tahun 1982 tentang Hak Cipta adalah karena pengaturan jenis tindak pidana pelanggaran hak cipta dalam UU No. 6 Tahun 1982 adalah delik aduan sehingga dianggap tidak sesuai kebutuhan. Penjelasan Umum UU No. 7 Tahun 1987 tentang Perubahan Atas UU No. 6 Tahun 1982 tentang Hak Cipta menegaskan, "masih dalam upaya untuk meningkatkan efektivitas penindakan, ketentuan bahwa pelanggaran terhadap hak cipta merupakan tindak pidana aduan, juga dinilai tidak sesuai dengan kebutuhan. Pelanggaran tersebut seharusnya memang diperlakukan sebagai tindak pidana biasa. Penindakannya, dengan begitu tidak lagi semata-mata didasarkan pada adanya pengaduan".

Dengan demikian, pengaturan jenis tindak pidana pelanggaran hak cipta sebagai suatu delik aduan sebagaimana ditetapkan dalam Undang Undang Nomor 28 Tahun 2014 tentang Hak Cipta adalah merupakan langkah mundur jauh ke belakang. Termasuk perubahan ancaman hukuman terhadap pelanggar hak cipta yang menurut UU No. 28 Tahun 2014 ini telah menghapuskan ancaman hukuman minimal. 
Bernard Nainggolan mengemukakan, "sangat dis- ayangkan di luar apa yang dikehendaki masyarakat, UUHC 2014 justru mendegradasi kedudukan tindak pidana hak cipta dari delik biasa menjadi delik aduan. Ini adalah kemunduran dalam rangka memajukan upaya perlindungan hak cipta di Indonesia. Lebih lanjut beliau mengemukakan bahwa langkah pembuat UUHC 2014 yang mengembalikan tindak pidana hak cipta menjadi delik aduan (sama seperti dalam UUHC tahun 1982) adalah kontradiktif dengan semangat men- ingkatkan penegakan hak cipta sebagaimana tercantum dalam penjelasan umum Undang Undang Nomor 28 Tahun 2014 tentang hak cipta, yaitu : "Langkah Dewan Perwakilan Rakyat Republik Indonesia dan Pemerin- tah mengganti Undang Undang Nomor 19 Tahun 2002 tentang Hak Cipta dengan undang undang ini adalah upaya sungguhsungguh dari negara untuk melindungi hak ekonomi dan hak moral Pencipta dan pemilik Hak Terkait sebagai unsur penting dalam pemnbangunan kreativitas nasional. Teringkarinya hak ekonomi dan hak moral dapat mengikis motivasi para Pencipta dan pemilik Hak Terkait untuk berkreasi. Hilangnya moti- vasi seperti ini akan berdampak luas pada runtuhnya kreativitas makro bangsa Indonesia. Bercermin kepada negara-negara maju, tampak bahwa perlindungan yang memadai terhadap hak cipta telah berhasil membawa pertumbuhan ekonomi kreatif secara signifikan dan memberikan konstribusi nyata bagi perekonomian dan kesejahteraan rakyat".

\section{KESIMPULAN DAN SARAN}

Secara perdata, atas pelanggaran hak eksklusif pencipta lagu atau musik, undang-undang memberikan perlindungan hukum bagi pencipta atau pemegang hak ciptanya untuk mengajukan gugatan ganti rugi melalui Pengadilan Niaga. Pemegang hak cipta dapat meminta ke Pengadilan Niaga untuk menarik dari peredaran dan menyita serta menyimpan sebagai alat bukti yang berkaitan dengan pelanggaran hak ciptanya. Termasuk menghentikan pelanggaran guna mencegah kerugian yang lebih besar. Dengan ditetapkannya Pengadilan Niaga sebagai lembaga yang berwenang untuk memu- tus sengketa hak cipta, maka asas peradilan cepat dan kepastian hukum dapat segera diwujudkan, mengingat ditetapkannya batas waktu untuk menyelesaikan dan memutus tuntutan ganti rugi tersebut selama 90 (sem- bilan puluh) hari sejak gugatan didaftarkan dan dapat diperpanjang paling lama 30 (tiga puluh) hari atas persetujuan MARI. Terhadap putusan Pengadilan Ni- aga tersebut hanya tersedia upaya hukum kasasi yang dalam jangka waktu 90 (sembilan puluh) hari setelah permohonan kasasi diterima, MA-RI harus memberi- kan putusan atas permohonan kasasi tersebut.

\section{DAFTAR PUSTAKA}

Hendra Tanu Hendra, Hak Cipta Musik atau lagu, Jakarta: Fakultas Hukum Pascasarjana Universitas Indonesia, 2003.

Hulman Panjaitan dan Wetmen Sinaga, Performing Right Hak Cipta Atas Karya Musik dan Lagu serta Aspek Hukumnya, Jakarta : Indohill-co, 2010.

Nainggolan Bernard, Komentar Undang Undang Hak Cipta, PT. Alumni Bandung, 2014.

Otto Hasibuan, Hak Cipta Di Indonesia, Tijauan Khusus Hak Cipta Lagu, Neightboring Rights dan Collecting Society, Bandung : Alumni, 2008.

Rooseno Hardjowidigdo, Perjanjian Lisensi Hak Cipta Musik Dalam Pembuatan Rekaman, Jakarta : Perum Percetakan Negara RI. 
